\title{
2018 Yılı Coğrafya Öğretmenliği Lisans Programının Alan Bilgisi, Genel Kültür ve Pedagoji Dersleri Açısından Analizi*
}

\section{Analysis of 2018 Geography Teacher Education Undergraduate Program in terms of Scientific Field Knowledge, General Culture and Pedagogy Courses}

\author{
Doç. Dr. Mustafa SAĞDIÇ (D) 1
}

\begin{abstract}
$\ddot{O} \mathbf{z}$
Bu araştırmanın amacı, Türkiye'de 2018 yılında uygulamaya konulan Coğrafya Öğretmenliği Lisans Programını Öğretmenlik Meslek Bilgisi, Genel Kültür, Alan Bilgisi, Alan Eğitimi ve Öğretmenlik Uygulaması dersleri bağlamında önceki program ile karşllaştırarak değerlendirmektir. Araştırmada nitel araştırma yöntemlerinden doküman analizi yöntemi kullanılmıștır. Doküman analizi sonucunda elde edilen bulgular içerik analizi tekniği ile çözümlenmiştir. Elde edilen bazı bulgular şunlardır: Alan bilgisi ile alana ilişkin öğretimi içeren dersler Alan Eğitimi başlığında toplanmıştır. Bu kapsamdaki derslerin ders saatleri ve kredileri önemli ölçüde azaltılmıştır. Buna karşılık Öğretmenlik Meslek Bilgisi derslerinin ders saatleri ve kredileri büyük ölçüde arttırılmıştır. Genel kültür derslerinin kapsamında da önemli değişiklikler söz konusudur. Öğretmenlik uygulaması dersi Öğretmenlik Uygulaması I ve Öğretmenlik Uygulaması II dersi olarak iki döneme çıkartılmıştır. Ancak öğretmenlik uygulamasına bir basamak teşkil eden Okul Deneyimi dersi ise programdan kaldırılmıştır. Lisans programlarının toplam kredileri 165 'dan 148 'ye, toplam ders saati ise 182 'den 157 'ye çekilmiştir. Ayrıca programda seçmeli derslere $\% 25$ oranında yer verilmiş, seçmeli ders çeşitliliği arttırılmış ve Bologna sürecine uyum sağlanmıştır. 2018 programı önceki programa göre merkezi bir yaklaşımın ürünü olarak yerel farklılıkları önemli ölçüde ortadan kaldırmıştır. Elde edilen bulgular ilgili literatür ile tartışılmış ve alana yönelik bazı öneriler geliştirilmiştir. Bu kapsamda yeni öğretmen yetiştirme lisans programları ile ilgili akademik çalışmaların artırılması önerilmektedir.
\end{abstract}

Anahtar Kelimeler: Coğrafya eğitimi, yeni lisans programı, öğretmen yetiştirme

Makale Türü: Araştırma

\begin{abstract}
The purpose of this study is to evaluate the geography teacher education program in the context of scientific field knowledge related to geography, professional teaching knowledge, general culture, geography education and teaching practice lessons implemented since 2018 in Turkey and containing important changes according to the previous program. In this study, document analysis method which is one of the qualitative research methods is used. The findings were analyzed by using descriptive analysis technique. It is seen that the new geography program is concerned with creating a standard in the faculties of education. The scientific field knowledge related to geography and teaching of geography were collected in the title of scientific field education. Hours and credits values of scientific field courses related to geography have been significantly reduced. On the other hand, the course hours and credits values of the teaching courses have been increased significantly. There are significant changes in the scope of general culture courses. Teaching practice was added to two semesters as Teaching Practice I and Teaching Practice II. However, the School Experience course, which constitutes a step in the teaching practice, has been removed from the program. The total credits of the undergraduate programs were reduced from 156 to 147 and the total course hours from 170 to 154. In addition, $25 \%$ of elective courses

\footnotetext{
*Bu çalışmanın bir bölümü 13.12.2019 tarihinde İstanbul'da düzenlenen 6. Yıldız Uluslararası Sosyal Bilimler Kongresinde bildiri olarak sunulmuştur.

${ }^{1}$ Yıldız Teknik Üniversitesi, Eğitim Fakültesi, msagdic@yildiz.edu.tr.
}

Atıf için (to cite): Sağdıç, M. (2019). 2018 yılı coğrafya öğretmenliği lisans programının alan bilgisi, genel kültür ve pedagoji dersleri açısından analizi. Afyon Kocatepe Üniversitesi Sosyal Bilimler Dergisi, 22(1), 130-144. 
were given in the program, the diversity of elective courses was increased and the process was adapted to the Bologna process.

Keywords: Geography education, undergraduate program, teacher training

Paper Type: Research

\section{Giriş}

Türkiye'de modern anlamda ilk coğrafya eğitimi Osmanlı Döneminde başlamıştır. 18. yüzyıldan itibaren Osmanlı Devletinin Batı karşısındaki savaşlarda aldığı ağır yenilgiler, Avrupa'daki teknik gelişmelere ilginin artmasına ve de coğrafya biliminin askeri stratejinin bir aracı olarak görülmesine neden olmuştur. Bu kapsamda Avrupa' daki teknik gelişmeleri Osmanlı topraklarına taşımak maksadıyla askeri okullar açılmış ve bu okulların programlarında coğrafya ve harita bilgisi derslerine de yer verilmiştir. Askeri okullarla başlayan modernleşme girişimlerini Tanzimat Döneminde sivil alana da taşımak ve devlete memur yetiştirmek amaciyla açılan rüşdiyelerin programlarında da coğrafya dersleri vardır (Yeşiltepe, 2010, s. 3235). Tanzimat döneminde çoğunluğu batıdaki eserlerin tercümesi olan çok sayıda coğrafya ders kitabı yazılmıştır. 1869 Maârif-i Umûmiye Nizamnâmesi ile dönemin ilkokulları olan Sıbyan Mekteplerinde de Elifba, Kur'an-1 Kerim, Tecvid, İlm-i Hâl, Ahlak, Sarf-1 Osmanî, İmlâ, Kıraat, Hesap, Hüsn-i Hat ve Mülahhas Tarih-i Osmanî dersleri ile beraber Muhtasar Coğrafyayı Osmanî dersleri de yer almıştır (Baltacı, 1999, s. 447). Yine 1869 Maârif-i Umûmiye Nizamnâmesi ile açılması kararlaştırılan idadi ve sultanilerin programlarında da coğrafya dersleri vardır. Cumhuriyet döneminde de 1962 yılına kadar ilkokuldan liselere kadar hemen her kademede müstakil coğrafya dersleri programlarda yer almıştır. Coğrafya dersleri erken Cumhuriyet döneminde ilkokul, ortaokul ve liselerde okutulmakta iken, günümüzde ise lise ve dengi okullarda bir genel kültür dersi olarak okutulmaktadır. Ayrıca liselerin sosyal bilimler ve edebiyat şubelerindeki ders programlarında bir uzmanlık dersi olarak daha yoğun şekilde yer almaktadir.

Coğrafya derslerini okutacak coğrafya öğretmenlerinin yetiştirilmesi Osmanlı'dan günümüze önemli bir konu olarak karşımıza çıkmaktadır. 1838'de devlete memur yetiştirmek amacıyla kurulan orta düzeyli rüşdiye mekteplerinin öğretmen ihtiyacını karşılamak için 1948 'de, üç yıllık öğrenim süresine sahip ilk öğretmen okulu olan Darülmuallimîn açılmış, ögretim programında Usûl-i ifade ve talim ve lisan-ı Farisi, riyâziyât, fenn-i hesap, hendese, mesaha ve heyet derslerinin yanı sıra coğrafya derslerine de yer verilmiştir (Gündüz, 2016, s. 239-240). 1869 Maârif-i Umûmiye Nizamnâmesi ile Osmanlı Devletinde öğretmen yetiştirme konusu tekrar gündeme gelmiş ve bu kapsamda 1891 yılında idâdî ve sultanilerin öğretmen ihtiyacını karşılamak için Darülmuallimîn-i Ali açılmıştır. Darülmuallimîn-i Ali, Cumhuriyet dönemindeki adıyla Yüksek Muallim Mektebi ya da Yüksek Öğretmen Okulu, 1978 tarihine kadar çeşitli değişikliklere rağmen lise ve dengi okullara öğretmen yetiştiren bir kurum olarak Türk eğitim tarihinde yerini almıştır (Eşme, 2001). 1925 Yüksek Muallim Mektebi Talîmâtnâmesinde okulun eğitim süresinin dört y1l olduğu ve yedi bölümden oluştuğu bildirilmiştir: Edebiyat, Felsefe-İctimâiyât, Tarih-Coğrafya, Riyâziyat, Fizik-Kimya, Tabîat, Sanâyi-i Nefìse. İlk üç yll alan derslerinin üniversitede alınmasından sonra, son sene staj dönemine ayrılmıştır (Maarif Vekâleti, 1927). 1908'den itibaren Dârülmuallimîn-i Âlî öğrencilerinin bazı dersleri Dârülfünûndan almaya başlaması, Türkiye'de öğretmen eğitiminde üniversite etkisi açısından bir milat olarak değerlendirilebilir. Dârülmuallimîn-i Âlî ile Darülfünun arasında başlayan bu ilişki bir süre sonra, Dârülmuallimîn-i Âlî’nin kapatılmasına ve derslerin tamamen Darülfunun'da verilmeye başlamasına neden olmuştur. Ancak bu uygulamanın da öğretmenlik meslek bilgisi derslerinin aksamasına neden olduğu gerekçesiyle, yoğun eleştiriler yapılmış ve 1911'de Âlî şubesi Dârülfünûndan ayrılarak dersler yeniden Dârülmuallimînde verilmeye başlamıştır (Satı, 1918). 1915 öğretim yılında Âlî şubesinin alan dersleri programı, öğrencilerin sınav ve sınıf geçme usûlleri Dârülfünûnun yönetmeliğine tâbi tutularak günümüzde de önemli bir tartışma konusu olan öğretmen yetiştirmede Eğitim 
Fakülteleri ile Fen-Edebiyat Fakülteleri arasındaki rol çatışmalarının temelleri atılmıştır. Esasen o günden günümüze kadar öğretmen yetiştirmede Eğitim Fakülteleri ile Fen-Edebiyat Fakülteleri arasında sağlıklı bir ilişki kurulamamıştır. Alan bilgisi derslerinin üniversiteden alınmasına ilişkin sözü edilen uygulama Cumhuriyet döneminde de uzun bir süre devam etmiştir.

1915 y1lında Darulfünun bünyesinde coğrafya bölümünün kurulması, Türkiye'de coğrafya biliminin gelişiminde önemli bir dönüm noktasıdır. Coğrafya bölümünün kurulması coğrafya eğitiminin gelişmesinde ve coğrafya biliminin gerçek anlamıyla bir akademik disiplin haline gelmesinde çok önemli bir rol üstlenmiştir. Diğer yandan 1946 yılında çıkarılan üniversiteler yasası ile öğretim üyelerinin üniversite dışında görev almasının yasaklanması Yüksek Öğretmen Okullarını derin bir şekilde etkilemiştir. Çünkü bu yasa gereğince öğretim üyelerinin Yüksek Öğretmen Okulları ile ilişkilerinin kesilmesi, bu okulların toplum nezdindeki itibarının hızla azalmasında etkili olmuştur (Aycan, 2015, s. 62).

Yüksek Öğretmen Okullarında Tarih ve Coğrafya şubesi bazen tek bölüm olarak yer almış, bazen de iki ayrı bölüm olarak kurumsallaştırılmıştır. İki ayrı bölüm olarak yapılandırıldığ 1 durumlarda da tarih bölümlerinde coğrafya, coğrafya bölümlerinde de tarih derslerine önemli bir yer ayrılmıştır. Maksat bu uygulama ile yetişecek öğretmenlerin hem tarih hem de coğrafya derslerini okutabilmelerini sağlamaktır. Tarih ve coğrafya dersleri tek bir öğretmen tarafından yürütülmekte, öğretmen atamaları için yapılan sınavlarda bu iki dersten ortak sınav yapılmakta ve öğretmen adayının bu iki dersi de okutabilme niteliğine sahip olması istenmektedir (Maarif Vekilliği, 1939, s. 18). Tarih ve coğrafya derslerinin tek bir öğretmen tarafından okutulmasına ilişkin uygulama, önemli sorunlara neden olmasına rağmen uzun süre devam etmiştir.

1960'lı y1llarda Tarih, Coğrafya ve Yurttaşlık Bilgisi derslerinin Sosyal Bilgiler olarak birleştirilmesi nedeniyle 1967-1968 yılından itibaren eğitim enstitülerine bağlı edebiyat bölümünün sosyal bilgiler kısmında sosyal bilgiler öğretmenleri yetiştirilmeye başlanmıştır (Bayram, 2003). Eğitim enstitülerinin 1978-1979 yılından itibaren dört yıllık yüksek öğretmen okullarına dönüştürülmesi ile Sosyal Bilgiler bölümü kaldırılarak yerine Tarih-Coğrafya ve Coğrafya-Tarih bölümleri kurulmuştur (Ercan, 2009). 1980 Askeri Darbesi siyasi, sosyal ve ekonomik hayatın yanı sıra eğitimde de önemli değişimleri beraberinde getirmiştir. Bu kapsamda 1982 Anayasası ile Yüksek Öğretim Kurumunun (YÖK) kuruluşunun ardından 1983'de çıkartılan 2809 sayılı yasa ile öğretmen yetiştiren tüm kurumlar Milli Eğitim Bakanlığından alınarak üniversite bünyesine verilmiştir. Böylece Yüksek Öğretmen Okulları Eğitim Fakültelerine dönüştürülmüştür. Öğretmen yetiştirme sorumluluğunun üniversitelere devredilmesi, öğretmen yetiştirmenin bir uzmanlık alanı haline gelmesi ve bu alanda bilimsel bilgi üretilmesi ve birikim sağlanması adına önemli bir adım olmuştur (Özoğlu, 2010, s. 11).

1983 yılından itibaren eğitim fakülteleri yeniden yapılandırılmış, yeni kurulan Sosyal Bilgiler Bölümü içinde Tarih Eğitimi ve Coğrafya Eğitimi programlarına yer verilmiştir (Öztürk, 2006, s. 17-20). Ayrıca Tarih ve Coğrafya Eğitimi programlarının Sosyal Bilgiler dersinin öğretmenliğini yapabilecek yeterlikleri kazandıracak şekilde belirlendiği vurgulanmıştır (YÖK, 2007, s. 42). 1998'de Eğitim Fakülteleri bünyesinde Sosyal Bilgiler Eğitimi Anabilim Dalı'nın kurulması ile Tarih ve Coğrafya Öğretmenlikleri programları da yeniden düzenlenmiştir. $\mathrm{Bu}$ süreçte ilk ve ortaokullardaki Sosyal Bilgiler derslerinin de yürütmesi amacıyla konulmuş Tarih dersleri Coğrafya Öğretmenliği programlarından kaldırılmış ve Coğrafya Öğretmenliği programları sadece lise ve dengi okullar için öğretmen yetiştirmeye başlamıştır.

1997 yılında 8 yıllık kesintisiz zorunlu ilköğretime geçilmesi ile beraber Eğitim Fakülteleri yeniden yapılandırılmış ve öğretim programları güncellenmiştir. Aynı yıl içinde ortaöğretim fen ve ortaöğretim sosyal alan öğretmenliği bölümleri kurulmuş ve ortaöğretime öğretmen yetiştirme programlarının süresinin tezsiz yüksek lisans düzeyine yükseltilmesine 
karar verilmiştir (YÖK, 1998). Dolayısıyla ortaöğretim alan öğretmenliği lisans programları için 3,5 y1l alan bilgisi ve 1,5 y1l öğretmenlik meslek bilgisi ve alan eğitimi dersleri şeklinde düzenlenme yapılmıştır. $\mathrm{Bu}$ düzenleme Fen Edebiyat Fakülteleriyle Eğitim Fakültelerinin özellikle ortaöğretim alan öğretmenliği programlarında birlikte çalışmalarını gerektirmiştir. Böylece öğrencilerin mezuniyeti için 5 yıla çıkarılan lisans öğrenimi süresince ilk 7 yarıyılda alan derslerini Fen Edebiyat Fakültelerinden, sonraki üç yarıyılda da Öğretmenlik Meslek Bilgisi derslerini Eğitim Fakültelerinden almaları gerekmiştir. Ayrıca diğer fakülte mezunları arasından belirli kriterler ve kontenjan dahilinde tezsiz yüksek lisans programlarına öğrenci alınmasının yolu açılarak pedagojik formasyon uygulamasına son verilmiştir. Bu kapsamda önceki sistemde 18-21 kredi/saat olan öğretmenlik meslek bilgisi dersleri, 36-39 kredi/saate çıkarılmış ve uygulama derslerine daha fazla zaman ayrılmıştır (Ö̈zyar, 2001).

2010-2011 yılından itibaren diğer fakülte mezunları için uygulanan tezsiz yüksek lisans programları kapatılmış ve 2014-2015 öğretim yılından itibaren de ortaöğretim alan öğretmenliği programlarının öğrenim süresi 5 yıldan 4 yıla düşürülmüştür. Böylece diğer fakülte mezunlarının ortaöğretim alan öğretmeni olabilmeleri için tekrar pedagojik formasyon uygulamasına başlanmıştır.

Eğitim fakültelerinin öğretim programlarındaki en son güncelleme 2018 yılında yapılmıştır. Bu güncellemede yapılmasında; alan eğitimine yönelik derslerle, öğretmenlik meslek bilgisi derslerinin yeniden oluşturulması ve programlarda bunlara ağırlık verilmesi, öğretmenlik uygulamasının daha geniş bir zamana yayılması ile güncellenen ilk ve orta öğretim ders programlarıyla uyum sağlanması gibi nedenler etkili olmuştur. Alan bilgisi derslerinin sayısı ve kredisinin azaltılması, çok bilen öğretmenlerden ziyade öncelikle iyi ahlaklı, rol model, mesleki değer ve idealleri içtenlikle özümsemiş ve benimsemiş öğretmenlere ihtiyaç olduğu varsayımına dayandırılmıştır (YÖK, 2018, s. 6).

\section{Araștırmanın Amacı}

Araştırmanın temel amacı Türkiye'de 2018 yılında uygulamaya konulan yeni Coğrafya öğretmenliği lisans programını alan bilgisi, alan eğitimi ${ }^{2}$, meslek bilgisi, genel kültür ve öğretmenlik uygulaması dersleri bağlamında değerlendirmektir. Bu kapsamda yeni program önceki programlarla karşılaştırılarak incelenmiştir. Alan yazını incelendiğinde bu kapsamda bir çalışmaya rastlanmamıştır.

\section{Alt Problemler}

1. 2018 Coğrafya Öğretmenliği Lisans Programında alan bilgisi derslerine ne düzeyde yer verilmiştir? Önceki program ile ne gibi farkl1lıklar içermektedir?

2. 2018 Coğrafya Öğretmenliği Lisans Programında, alanın öğretimine ilişkin derslere ne düzeyde yer verilmiştir? Önceki program ile ne gibi farkl1l1klar içermektedir?

3. 2018 Coğrafya Öğretmenliği Lisans Programında, öğretmenlik meslek bilgisi derslerine ne düzeyde yer verilmiştir? Önceki program ile ne gibi farklılıklar içermektedir?

4. 2018 Coğrafya Öğretmenliği Lisans Programında, genel kültür derslerine ne düzeyde yer verilmiştir? Önceki program ile ne gibi farkl1lıklar içermektedir?

5. 2018 Coğrafya Öğretmenliği Lisans Programında okul uygulamalarına ne düzeyde yer verilmiştir? Önceki program ile ne gibi farkl11ıklar içermektedir?

\section{Yöntem}

Araştırmada nitel araştırma yaklaşımlarından doküman incelemesi yöntemi kullanılmıştır. Doküman incelemesi süreci beş aşamadan oluşmuştur; (1) dokümanlara ulaşma,

\footnotetext{
22018 programlarında alan bilgisi ile alana ilişkin öğretimi içeren dersler Alan Eğitimi başlığında toplanmıştır. Ancak bu çalışmada konunun daha iyi anlaşılması için Alan Bilgisi dersleri ayrı başlıkta değerlendirilmiştir.
} 
(2) orijinalliğin kontrol edilmesi, (3) dokümanların anlaşılması, (4) verilerin analiz edilmesi ve (5) verilerin kullanılmas1 (Forster, 1995, s. 151-152). Doküman incelemesinde elde edilen verilerin çözümlenmesinde toplanan dokümanların araştırmanın tek veri setini mi oluşturacağ ya da gözlem ve görüşme gibi diğer veri toplama yöntemlerine gereksinim duyulup duyulmayacağına karar verilmesi önemli bir aşamadır. Bu sırada Coğrafya Öğretmenliği Lisans Programları ve ders içeriklerinin tek veri seti olmasına karar verilmiştir.

\section{Verilerin Toplanması}

1980 sonrasında Yüksek Öğretim Kurumu tarafindan uygulamaya konulan Coğrafya Öğretmenliği Lisans Programlart ve ders içerikleri araştırmanın temel veri kaynağını oluşturmuştur. 1980 sonrasının esas alınmasında, 1983'de çıartılan bir yasa ile öğretmen yetiştiren tüm kurumların Milli Eğitim Bakanlığından alınarak üniversite bünyesine verilmesi ve bu tarihin öğretmen yetiştirmede bir dönüm noktası olması etkili olmuştur. Bu kapsamda 1983 Coğrafya Öğretmenliği Lisans Programı, 1998 Coğrafya Öğretmenliği Lisans ve Tezsiz Yüksek Lisans Programı, 2013 Coğrafya Öğretmenliği Lisans Programı, 2017 Coğrafya Öğretmenliği Lisans Programı ile 2018 Coğrafya Öğretmenliği Lisans Programı incelenmiştir.

\section{Verilerin Analizi}

İlgili dokümanlardan elde edilen veriler içerik analizi tekniği ile çözümlenmiştir. İçeriğin analizi sırasında metin içeriklerinin ortak yönlerini ortaya çıkarmak amaçlanmıştır. Bu süreçte, ilgili dokümanlar aracılığıyla elde edilen verilerin kavramsallaştıılması, bu kavramlara göre mantıksal bir çerçeve oluşturulması ve verileri açıklayan temaların oluşturulması planlanmıştır. Böylece verilerin içindeki gizil gerçeklerin ortaya çıkarılması mümkün olabilecektir (Yıldırım ve Şimşek, 2013, s. 227). Yine bu süreçte ilgili programlar ve ders içerikleri karşılaştırılarak farklılıkları ve benzerlikleri ortaya konulmaya çalışılmıştır. Bu kapsamda 1980 sonrası Coğrafya Öğretmenliği Lisans Programları ve ders içerikleri derinlemesine incelenmiştir. 2018 yılı Coğrafya Öğretmenliği Lisans Programı ve ders içeriklerinin önceki programlar ve ders içerikleri ile benzerlikleri ve farklılıkları belirlenmiştir.

Son aşamada öğretmen yetiştirme programlarının temel ayaklarını oluşturan alan bilgisi, alan eğitimi, ögretmenlik meslek bilgisi, genel kültür dersleri ve okul uygulamalar olarak 5 alt tema belirlenmiştir. İlgili temalar çerçevesince programlar ve ders içerikleri arasındaki farklılıkların nedenleri ve elde edilen bulgular, ilgili literatür aracılığıyla tartışılmış alana özgü değerlendirmelerde bulunulmuştur. Bu bağlamda Coğrafya Öğretmenliği Lisans Programının ve ders içeriklerinin olumlu ve olumsuz yönleri değerlendirilerek bazı önerilerde bulunulmuştur.

\section{Bulgular}

Öğretmen yetiştirme işi; öğretmenlik meslek bilgisi de denilen pedagoji bilgisi, alan bilgisi ve genel kültür olmak üzere üç temel ayak üzerine inşa edilmektedir (Stengel ve Tom, 1996, s. 593). 1982 yılında düzenlenen XI. Millî Eğitim Şûrasında Türkiye'deki eğitim fakültelerinde okutulan lisans derslerinin \%62,5'sinin Alan Bilgisi derslerine, \%25'inin Öğretmenlik Meslek Bilgisi (uygulama dâhil) derslerine ve \%12,5'inin Genel Kültür derslerine ayrılması önerilmiştir (YÖK, 2007, s. 20). Bu kapsamda hazırlanan 1983-1984 Coğrafya öğretmenliği programında toplam 211 saat ders bulunmaktadır. Bu derslerin \%60,7'si Alan Bilgisi derslerine ayrılmıştır. Alan Bilgisi derslerinin de \%45,5'i (96 saat) coğrafya derslerine, \%15,2'si (32 saat) tarih derslerine aittir. Öğretmenlik Meslek Bilgisi dersleri toplam ders saatinin \%11,4'ünü (24 saat) oluşturmaktadır. Bu dersler içinde Alan Eğitimi kapsamında sadece 3 saatlik $(\% 1,4)$ Coğrafya ve Sosyal Bilgiler Öğretim Yöntemleri adlı bir ders yer almaktadır. Öğretmenlik Uygulaması ise sadece 1 ay olarak planlanmıştır. Genel Kültür dersleri ise toplam derslerin \%26,5'ini (56 saat) oluşturmaktadır. Genel Kültür kapsamındaki derslerin \%57,1'ini (32 saat) Yabancı Dil dersi oluşturmuştur (YÖK, 2007, s. 163). 
Öğretmen yetiştirme işinin Eğitim Fakültelerine geçmesinin ardından ikinci kapsamlı program güncellemeleri $1997^{\prime}$ de 8 y1llık kesintisiz zorunlu ilköğretime geçilmesi nedeniyle Eğitim Fakültelerinin yeniden yapılandırılması sürecinde gerçekleştirilmiştir. 1998'deki bu güncelleme; ders sayıları, ders içerikleri ve öğretmenlik uygulamalarında fakülteler arasında bir standardın olmaması, ders içeriklerinin ilköğretim ve ortaöğretim okullarındaki ders içerikleri ile yeterince uyumlu olmaması, dersler arasında mantıksal bir ilişkinin yeterince kurulamaması, uygulama derslerinin büyük ölçüde göz ardı edilmesi, alan öğretimine ilişkin derslerin yetersiz olması, programlarda yeni açılan derslerin öğretmenlik alanının gereksinimlerinden ziyade alan bilgisi öğretim elemanlarının çalışma alanları ile ilgili olması ve bu nedenle ders sayısının gereğinden fazla artması, öğretmenlik meslek bilgisi derslerinin sadece teorik derslerden oluşması ve uygulamanın büyük ölçüde ihmal edilmesi, seçmeli derslere yeterince zaman ayrılmaması ve okul uygulamaları ile programın uyumlu olmaması gibi günümüzde de büyük ölçüde çözümlenemeyen sorunlara dayandırılmıştır (YÖK,1998, s. 4). Ayrıca 1998'de ortaöğretim alan öğretmenlikleri tezsiz yüksek lisans düzeyine yükseltilmiştir. 1998-1999 öğretim y1lından itibaren uygulanmaya başlayan ilgili yönetmeliğe göre ortaöğretim alan öğretmenleri için iki tür program uygulanmıştır. Birincisine göre $(3,5+1,5$ y1l $)$ Eğitim Fakültesinde Coğrafya Öğretmenliğini kazanan öğrenciler ilk yedi yarıyıl derslerini FenEdebiyat Fakültesi Coğrafya Bölümünden alıp, başarı ile tamamladıktan sonra, lisans kademesinin son yarıyılında eğitim fakültesinde alan eğitimi ve öğretmenlik uygulaması derslerini alarak lisans diploması almaya hak kazanmaktadırlar. Ardından yine bu öğrenciler enstitüdeki coğrafya öğretmenliği tezsiz yüksek lisans programına doğrudan kaydedilerek en çok iki yarıyılda tezsiz yüksek lisans mezunu olabilmektedirler. Bu seçenek, Eğitim Fakülteleri ile alan fakültelerinin ortaklaşa yürüttüğü tezsiz yüksek lisans programını ifade etmektedir. İkinci uygulama ise (4+1,5 yıl) üniversite sınavında Fen- Edebiyat fakültesi Coğrafya bölümünü kazanıp, bu bölümü başarıyla tamamlayan ve öğretmen olmak isteyen öğrencilerden tezsiz yüksek lisans şartlarını sağlayanlar için uygulanan ve lisans mezuniyetinden sonra en çok üç yarıyıl süren bir tezsiz yüksek lisans programıdır. Bu uygulamalardan ilki lisans öğretiminin başından itibaren bir ortaöğretim alan öğretmenliği programı olup öğrenciler lisans programlarına eğitim fakültesinin öğrencisi olarak kayıt hakkı elde etmişlerdir.

1998 programı 1983'deki programa göre alan bilgisi, pedagoji bilgisi ve genel kültür dersleri bağlamında önemli farklılıklar içermektedir. İlk yedi yarıyılda alınan derslerin tamamı alan bilgisi ve genel kültür dersleri olup, Fen Edebiyat Fakültesinin ilgili bölümünden alınmaktadır. Fen Edebiyat Fakülteleri arasında ortak bir program olmadığından fakülteler arasında toplam kredilerde farklıl1klar söz konusudur. Bununla beraber ortalama yedi yarıyılda 140-150 kredilik bir ders alınmaktadır. Bu derslerin yaklaşık \%15'lik kısmı (20-25 kredi) genel kültür derslerine ayrılmıştır. Tezsiz yüksek lisans derslerinde ise ülke genelinde ortak bir program söz konusu olup Öğretmenlik Meslek Bilgisi, Alan Eğitimi ve Öğretmenlik Uygulamasını kapsayan 45 kredilik bir ders programı uygulanmıştır. Dolayısıyla toplam derslerin yaklaşık \% 25'i Öğretmenlik Meslek Bilgisi derslerine aittir. Ayrıca programda Alan Eğitimi dersleri Meslek Bilgisi dersleri kapsamında değerlendirilmiştir. Yine Meslek Bilgisi derslerinin içindeki Özel Öğretim Yöntemleri I ve II, Konu Alanı Ders Kitabı ile Öğretmenlik Uygulaması dersleri alan eğitimi dersleri olarak ayırt edilebilir. Bu dersler toplam kredinin \% 7,5'ini, Öğretmenlik Meslek Bilgisi derslerinin ise yaklaşık \% 30’unu oluşturmuştur.

1998 yılındaki kapsamlı güncellemesinin ardından 2006 tarihli YÖK Genel Kurulundaki alınan karar gereğinde Eğitim Fakülteleri programları yeniden güncellenmiştir. Ancak bu güncelleme ilköğretim programları ile sınırlı tutulmuştur. 2010 yılında Ortaöğretim Alan Öğretmenliği Tezsiz Yüksek Lisans programları uygulamadan kaldırılmış ve Ortaöğretim Alan Öğretmenliği programlarındaki Öğretmenlik Meslek Bilgisi dersleri birinci sınıftan son sınıfa kadar tüm yıllara dağıtılmıştır. 2014 yılında ise Yüksek Öğretim Kurumu'nun aldığı bir kararla Ortaöğretim Alan öğretmenliklerinin süresi 5 yıldan 4 yıla indirilmiştir. Böylece diğer fakülte mezunları için daha önceden var olan pedagojik formasyon uygulamasına tekrar başlanmıştır. 
En son güncellemeler ise 2018 yılında gerçekleşmiştir. Bu kapsamda tüm öğretmen yetiştirme programları güncellenmiştir. Yeni Coğrafya Öğretmenliği Lisans Programı, önceki öğretim programına göre önemli değişiklikler ihtiva etmektedir. 2018 öncesinde özellikle Ortaöğretim Alan Öğretmenlikleri programında genel bir standart söz konusu olmadığından haftalık ders saati, ders kredisi ve AKTS değerleri üniversiteler ve fakülteler arasında farklılık göstermektedir. Ancak 2018 programlarda ulusal krediler ve AKTS değerleri tüm fakülteler için sabitlenmiş ve derslerin dönemlerinin de değiştirilmesine kesin olarak izin verilmeyeceği belirtilmiştir (YÖK, 2018, s. 20). Dolayısıyla 2018 programlarının ülke genelinde standart bir uygulamayı zorunlu kılması, bu güncellemelerin en önemli özelliklerinden biridir.

Tablo 1.2017 ve 2018 coğrafya öğretmenliği lisans programlarının karşılaştırılması

\begin{tabular}{lccccccccccc}
\hline & \multicolumn{9}{c}{ 2017 Program1 } & \multicolumn{4}{c}{2018 Program1 } \\
\hline & T & U & K & SAAT & YÜZDE & T & U & K & SAAT & YÜZDE \\
\hline Meslek Bilgisi & 31 & 16 & 39 & 47 & 20 & 44 & 12 & 50 & 56 & 34 \\
\hline Alan Eğitimi & 91 & 14 & 98 & 105 & 66 & 69 & 4 & 71 & 73 & 48 \\
\hline Genel Kültür & 26 & 4 & 28 & 30 & 14 & 26 & 2 & 27 & 28 & 18 \\
\hline TOPLAM & 148 & 34 & 165 & 182 & 100 & 139 & 18 & 148 & 157 & 100 \\
\hline
\end{tabular}

2018 öncesinde ortalama ders kredileri ve saatleri düşünüldüğünde Coğrafya Öğretmenliği lisans programlarının toplam kredi sayıları 165 iken 2018'de 148'e indirilmiştir. Toplam ders saati ise 182'den 157'e çekilmiştir. Dolayısıyla toplam krediler ortalama $17 \mathrm{kredi}$, toplam ders saatleri ise 25 saat azaltılmıştır (YÖK, 2018, s. 19). Bu kapsamda Öğretmenlik Meslek Bilgisi dersleri önemli ölçüde arttırılmıştır. Meslek Bilgisi derslerinin saatleri 47'den 56'ya; kredileri ise 39'dan 50'ye çıkarılmıştır. Ayrıca Meslek bilgisi derslerinin içeriklerinde de önemli değişiklikler söz konusudur.

\section{1. Öğretmenlik Meslek Bilgisi Derslerindeki Yeni Düzenlemeler}

Öğretmenlik Meslek Bilgisinin ağırlığ 2017 programında \%20 iken 2018 programında \%34'e çıkarılmıştır. Öğretmenlik Meslek Bilgisi derslerinin 2018 programında ders saati ve kredisinin önemli ölçüde artırılması yeni programın en dikkat çeken özelliklerinden birisidir. Önceki programda Öğretmenlik Meslek Bilgisi dersleri içinde Eğitim Bilimine Giriş, Sınıf Yönetimi, Eğitim Psikolojisi, Öğretim İlke ve Yöntemleri, Türk Eğitim Sistemi ve Okul Yönetimi, Ölçme ve Değerlendirme, Rehberlik, Türk Eğitim Tarihi, Öğretim Teknolojileri ve Materyal Tasarımı, Özel Öğretim Yöntemleri I ve II, Program Geliştirme, Özel Eğitim, Okul Deneyimi, Öğretmenlik Uygulaması, Seçmeli I ve Seçmeli II dersleri vardır. 2018 Coğrafya Öğretmenliği programında ise Öğretmenlik Meslek Bilgisi dersleri; Eğitime Giriş, Öğretim İlke ve Yöntemleri, Eğitimde Ölçme ve Değerlendirme, Türk Eğitim Sistemi ve Okul Yönetimi, Sınıf Yönetimi, Eğitim Felsefesi, Eğitim Psikolojisi, Eğitim Sosyolojisi, Eğitimde Araştırma Yöntemleri, Öğretim Teknolojileri, Türk Eğitim Tarihi, Eğitimde Ahlâk ve Etik, Öğretmenlik Uygulaması 1 ve 2, Okullarda Rehberlik, Özel Eğitim ve Kaynaştırma, Seçmeli I, Seçmeli 2, Seçmeli 3, Seçmeli 4, Seçmeli 5 ve Seçmeli 6 derslerinden oluşmuştur.

Önceki programdaki Öğretim Teknolojileri ve Materyal Tasarımı dersi programdan kaldırılmış, yerine Öğretim Teknolojileri adlı yeni bir ders konulmuştur. Ayrıca Materyal Tasarımı adlı seçmeli bir ders oluşturulmuştur. Ölçme ve Değerlendirme dersinin adı Eğitimde Ölçme ve Değerlendirme, Rehberlik dersinin adı Okullarda Rehberlik, Bilimsel Araştırma Yöntemleri dersinin adı Eğitimde Araştırma Yöntemleri dersi olarak değiştirilerek içeriği de bu kapsamda yeniden düzenlenmiştir. Özel Öğretim Yöntemleri dersleri, Öğretmenlik Meslek Bilgisi dersleri kapsamından, Alan Eğitimi dersleri kapsamına aktarılmış, ismi Coğrafya Öğretimi 1 ve Coğrafya Öğretimi 2 olarak değiştirilerek içeriği yeniden oluşturulmuştur. Özel Eğitim dersi, Özel Eğitim ve Kaynaştırma olarak güncellenmiştir. Okul Deneyimi dersi kaldırılarak Öğretmenlik Uygulaması dersi iki dönem olarak yeniden düzenlenmiştir. Eğitim Bilimine Giriş dersi Eğitime Giriş olarak değiştirilmiş ve içeriği güncellenmiştir. 2017 programındaki Eğitim Psikolojisi dersinin yanı sıra Eğitim Sosyolojisi ve Eğitim Felsefesi 
dersleri zorunlu dersler olarak programa eklenmiştir. Ayrıca Eğitimde Ahlâk ve Etik dersi yeni eklenen dersler arasindadir.

Öğretmenlik Meslek Bilgisi ile ilgili seçmeli derslerin sayısı da önemli ölçüde arttırılmıştır. Öğretmenlik Meslek Bilgisi seçmeli ders havuzuna daha önceki programlarda hiç yer almayan çok sayıda yeni ders eklenmiştir. 2018 programındaki Öğretmenlik Meslek Bilgisi seçmeli dersleri; Açık ve Uzaktan Öğrenme, Çocuk Psikolojisi, Dikkat Eksikliği ve Hiperaktivite Bozukluğu, Eğitim Hukuku, Eğitim Antropolojisi, Eğitim Tarihi, Eğitimde Drama, Eğitimde Program Dışı Etkinlikler, Eğitimde Program Geliştirme, Eğitimde Proje Hazırlama, Eleştirel ve Analitik Düşünme, Hastanede Yatan Çocukların Eğitimi, Kapsayıcı Eğitim, Karakter ve Değer Eğitimi, Karşılaştırmalı Eğitim, Mikro Öğretim, Müze Eğitimi, Okul Dış1 Öğrenme Ortamları, Öğrenme Güçlüğü, Öğretimi Bireyselleştirme ve Uyarlama, Sürdürülebilir Kalkınma ve Eğitim, Yetişkin Eğitimi ve Hayat Boyu Öğrenme dersleridir.

\section{Alan Bilgisi ve Alan Öğretimi Derslerindeki Yeni Düzenlemeler}

2018 Coğrafya Öğretmenliği lisans programında alan ve alan eğitimi dersleri birlikte değerlendirilerek "Alan Eğitimi” başlığı altında ele alınmıştır. Oysa önceki programlarda alanın öğretimine ilişkin dersler alan dersleri yerine, öğretmenlik meslek bilgisi dersleri ile birlikte değerlendirilmiştir. Ayrıca yeni programda Alan Eğitimi başlı̆̆ 1 altındaki derslerin saatleri 105 'den 73 'e; kredileri ise 98 'den 71 'e düşürülmüştür. Ders saatlerinde 32 saatlik bir azalma söz konusudur. Alan Eğitimi başlığı altında toplanan derslerin 2018 programında dramatik bir şekilde azaltılması yeni programın en dikkat çeken yanlarından birisidir.

Eski programda doğrudan Alan Bilgisi dersleri 96 saat iken, alana ilişkin öğretimi içeren dersler 9 saattir. Doğrudan Alan Bilgisi dersleri toplam kredinin yaklaşık \%60'ını, alanın öğretimine ilişkin dersler ise toplam kredinin yaklaşı $\% 5$ 'ini oluşturmuştur. Yeni programda ise Alan Bilgisi dersleri 61 saate düşürülmüştür. Bu dersler içinde 4 saatlik bir uygulama dersi yer almaktadır. Alanın öğretimine ilişkin dersler ise 12 saat olup, hepsi teorik derstir. Alan Eğitimi kapsamındaki derslerin \%84'ü Alan Bilgisi dersi, \%16'sı ise alanın öğretimine ilişkin derslerdir. Dolayısıyla yeni Coğrafya Öğretmenliği programında alanın öğretimine ilişkin derslerin toplam kredi içindeki oranı kısmen arttırılmıştır.

Önceki programda alanın öğretimiyle ilgili dersler; Alan Eğitiminde Araştırma Projesi ve Coğrafya Ders Kitapları İncelemeleri dersleridir. Yeni programda alanın öğretimi ile ilgili Özel Öğretim Yöntemleri derslerinin başına "Coğrafya" ibaresi getirilmiş ve içerik buna göre düzenlenmiştir. Öğretmenlik Meslek Bilgisi dersleri kapsamındaki Özel Öğretim Yöntemleri dersleri yeni programdan kaldırılmıştır. Yeni Coğrafya Öğretmenliği lisans programındaki alanın öğretimine ilişkin dersler: Coğrafya Öğretimi 1, Coğrafya Öğretimi 2, Coğrafya Öğrenme ve Öğretim Yaklaşımları ve Coğrafya Öğretim Programları dersleridir. Ayrıca Alan Eğitimi seçmeli dersleri arasında da alanın öğretimine ilişkin dersler yer almaktadır. Bu dersler: Coğrafya Ders Kitabı İncelemesi, Coğrafya Öğretiminde Materyal Tasarımı, Çevre Eğitimi, Eğitimde Harita Uygulamaları ve Sınıf İçi Öğrenmelerin Değerlendirilmesi dersleridir.

Alan Bilgisi ders saatleri ve kredilerinin dramatik bir şekilde azaltılması 2018 programının en dikkat çeken ve eleştiriye en açık yönünü oluşturmaktadır. Eski programda Alan Bilgisi derslerinin adları, içerikleri, kredileri ve saatleri konusunda üniversitelere geniş bir esneklik tanınmış olduğundan önemli farklılıklar söz konusudur. Ayrıca önceki Coğrafya lisans programlarında Coğrafyanın hemen hemen tüm bilim dalları ile ilgili ayrı ayrı derslere yer verilmiştir. 2018 öncesi Coğrafya Öğretmenliği lisans programlarında yer alan dersler; Coğrafyaya Giriş, Harita Bilgisi I ve II, Jeomorfoloji I ve II, Klimatoloji I ve II, Hidrografya I ve II, Bitki Coğrafyası I ve II, Toprak Coğrafyası, Nüfus Coğrafyası, Yerleşme Coğrafyası, Türkiye Fiziki Coğrafyası I ve II, Ekonomik Coğrafya I ve II (Bazı üniversitelerde bu derslerin yerine Ulaşım Coğrafyası, Sanayi Coğrafyası, Enerji Coğrafyası, Turizm Coğrafyası, Tarım Coğrafyası gibi Ekonomik coğrafyanın alt dalları ile ilgili dersler lisans programında yer almıştır), Siyasi Coğrafya, Türkiye Beşeri Coğrafyası, Türkiye Ekonomik Coğrafyası, Kıtalar 
Coğrafyası I ve II, Coğrafya Araştırma Teknikleri, Çevre Sorunları, Coğrafi Bilgisi Sistemleri, Türk Dünyas1 Coğrafyası, Türkiye Bölgeler Coğrafyası, Doğal Afetler I ve II ve Doğal Kaynaklar gibi derslerdir. Yeni programda tüm fakültelerde Alan Bilgisi dersleri standart hale getirilmiştir. Bu dersler: Coğrafyaya Giriş, Harita Bilgisi, Beşeri Coğrafya I ve II, Fiziki Coğrafya I ve II, Ekonomik Coğrafya I ve II, Kitalar ve Ülkeler Coğrafyası I ve II, Coğrafi Bilgi Sistemleri I ve II, Türkiye'nin Fiziki Coğrafyası, Türkiye'nin Beşeri ve Ekonomik Coğrafyası, Siyasi Coğrafya, Çevre Sorunları, Afetler ve Afet Yönetimi ve Arazi Çalışmaları dersleridir. Dolayısıyla yeni programda Jeomorfoloji, Klimatoloji, Hidrografya, Bitki Coğrafyası, Toprak Coğrafyası, Matematik Coğrafya, Nüfus Coğrafyası, Yerleşme Coğrafyası, Tarım Coğrafyası, Sanayi Coğrafyası ve Turizm Coğrafyası gibi Coğrafyanın bilim dalları ile ilgili dersler zorunlu dersler arasından çıkartılmıştır. Bu bilim dallarına ait konular Fiziki Coğrafya I ve II, Beşeri Coğrafya I ve II ve Ekonomik Coğrafya I ve II dersleri içerisinde birleştirilmiştir. Yeni programdaki Arazi Çalışmaları dersi 4 saatlik bir uygulama dersi olarak planlanmıştır. Coğrafi Bilgi Sistemleri I ve Coğrafi Bilgi Sistemleri II dersleri 2'şer saatlik teorik ders olarak tasarlanmış ve uygulama saatlerine yer verilmemiştir.

Alan bilgisi ve alan öğretimine ilişkin seçmeli dersler YÖK tarafından oluşturulmuştur. Bu seçmeli dersler içinde Bitki Coğrafyası, Kültürel Coğrafya, Matematiksel Coğrafya, Türkiye Turizm Coğrafyası ve Yakın Çevrenin Mekânsal Analizi dersleri Alan Bilgisi dersleridir. Coğrafya Ders Kitabı İncelemesi, Coğrafya Öğretiminde Materyal Tasarımı, Çevre Eğitimi ve Eğitimde Harita Uygulamaları dersleri alanın öğretimine ilişkin derslerdir. Sınıf İçi Öğrenmelerin Değerlendirilmesi ve Ekonomi ve Finans Okuryazarlığı dersleri ise esasen Alan Eğitimi kapsamında değildir. Sınıf İçi Öğrenmelerin Değerlendirilmesi dersi Öğretmenlik Meslek Bilgisi dersleri kapsamında bir ders olarak değerlendirilebilir. Ekonomi ve Finans Okuryazarlığ dersi ise Genel Kültür dersleri arasına alınabilir.

Alan Eğitimi seçmeli ders havuzuna yeni ders eklenebilmesi de belirli prosedürlere tabi tutulmuştur. Bu kapsamdaki yeni bir ders, üniversitenin ilgili kurullarının onayı ve Yüksek Öğretim Kurumu'nun izni doğrultusunda eklenebilmektedir. Ayrıca Alan Eğitimi seçmeli ders havuzuna en fazla 6 ders eklenebilmekte ve bu derslerin de alanın öğretimi ile ilgili olması şart koşulmaktadır.

\section{Genel Kültür Derslerindeki Yeni Düzenlemeler}

Öğretmen yetiştirmenin üç temel ayağından biri de Genel Kültür boyutudur. 2018 programında Genel Kültür dersleri ile ilgili önemli düzenlemeler söz konusudur. Zorunlu Genel Kültür derslerinden Atatürk İlkeleri ve İnkılap Tarihi 1 ve 2, Türk Dili 1 ve 2, Yabanc1 Dil 1 ve 2 dersleri programda yerini korumuştur. Bilgisayar I ve Bilgisayar II adlı 2'şer saatlik dersler programdan kaldırılarak Bilişim Teknolojileri adlı 3 saatlik yeni bir ders programa eklenmiştir. 2018 programında Genel Kültür kapsamındaki dersler ile ilgili en önemli değişiklikler seçmeli dersler ile ilgilidir.

Genel kültür seçmeli dersleri ile ilgili tüm fakülte için ortak bir seçmeli ders havuzu oluşturulmuştur. $\mathrm{Bu}$ dersler eğitim fakültelerinin tüm programları için ortak derslerdir. 2018 programındaki Genel Kültür seçmeli dersleri: Bilim Tarihi ve Felsefesi, Bilim ve Araştırma Etiği, Mesleki İngilizce, Bağımlılık ve Bağımlılıkla Mücadele, Ekonomi ve Girişimcilik, İnsan Hakları ve Demokrasi Eğitimi, Beslenme ve Sağlık, İnsan İlişkileri ve İletişim, Geleneksel Türk El Sanatları, Sanat ve Estetik, Kariyer Planlama ve Geliştirme, Medya Okuryazarlığı, Türk İşaret Dili, Türk Sanatı Tarihi, Kültür ve Dil, Türk Halk Oyunları, Türk Musikisi ve Türk Kültür Coğrafyası dersleridir. Genel Kültür seçmeli ders havuzuna Yüksek Öğretim Kurumunun onayı olmaksızın, üniversitenin ilgili kurullarının onayı ile yeni bir ders eklenebilmektedir. Genel kültür dersleri için fakülte yönetimi tarafindan bir koordinatörlüğün oluşturulması istenmiştir. Öğretmenlik Meslek Bilgisi dersleri ile Genel kültür dersleri için farklı programlardan öğrencilerin her dönem seçebileceği şekilde haftalık ders programlarının oluşturulması ve 
derslerin dönemlerinin fakülteler tarafindan değiştirilememesi programların sağlıklı bir şekilde devam ettirilebilmesi için gerekli görülmüştür.

\section{4. Öğretmenlik Uygulaması Derslerindeki Yeni Düzenlemeler}

Önceki programdaki Okul Deneyimi dersi programdan kaldırılmıştır. Buna karşılık yeni programda Öğretmenlik Uygulaması iki döneme çıkartılmıştır. Öğretmen adaylarının okullarda yaptığı uygulama süresi Okul Deneyimi dersinin öğretim programından kaldırılmasından dolayı esasen değişmemiştir. Bu süre son iki yarıyılı kapsayacak şekilde iki dönem ile sınırlıdır. Öğretmen adayları 4 yıllık lisans programının ancak son yılında okullarda uygulama yapabilmektedir. Ayrıca Öğretmenlik Uygulaması 1 dersi, Öğretmenlik Uygulaması 2 dersinin ön koşullu dersi olarak düzenlenmiştir.

\section{Tartışma ve Sonuç}

2018-2019 Eğitim-Öğretim yılından itibaren uygulanmaya başlayan yeni öğretmen yetiştirme programında toplam krediler ve ders saatleri önceki programlara göre azaltılmıştır. Önceki programlarda açılan bazı derslerin öğretmen adaylarının ilgi ve ihtiyaçlarından çok öğretim elemanlarının akademik yönelimleri ve tercihleri doğrultusunda şekillenmesi ve bu nedenle de ders sayıları ve zorunlu kredi yükünün gereğinden fazla artması programların güncellenme gerekçeleri arasındadır (YÖK, 2018, s. 12). Ayrıca öğretmen yetiştirme programlarında ders saatlerinin azaltılmasının öğretmen adaylarının kişisel gelişimlerine daha fazla zaman ayırabilmeleri, sosyal ve kültürel faaliyetlere katılabilmeleri ve okullardaki öğretmenlik uygulamalarına daha kolaylıkla gidebilmeleri açısından önemli olduğu düşünülmektedir.

2018 Coğrafya Öğretmenliği lisans programındaki en dikkat çeken değişiklik Alan Bilgisi ders saatleri ve kredilerinin dramatik bir şekilde azaltılmasıdır. Önceki programda toplam kredilerin yaklaşık \%60'1 doğrudan Alan Bilgisi ile ilgilidir. Yeni programda ise doğrudan alan bilgisi ile ilgili dersler toplam kredinin yaklaşı \%41'ini oluşturmaktadır. Programın içinde Alan Bilgisi derslerinin sayısının bu denli azaltılması; Coğrafya Öğretmenliği mezunlarının Kamu Personeli Seçme Sınavında (KPSS) başarısız olmalarına, bilgi eksikliğini gidermek için daha fazla dershanelere yönelmelerine ve Fen Edebiyat Fakültesi mezunlarına kıyasla alan bilgisi açısından belirgin şekilde yetersizliğin ortaya çıkmasına ve öğretmen yetiştirmenin lokomotifi olan Eğitim Fakültelerine olan güvenin azalmasına neden olabilir. Nitekim Türkiye'de öğretmen atamalarının ön şartı olan KPSS sınavlarındaki soruların \% 40'1 doğrudan alan bilgisi sorularından oluşmaktadır. Yine bu sınavların öğretmen adayları üzerinde oluşturduğu psikolojik baskı onların fakültedeki dersleri ikinci plana atarak daha fazla dershanelere yönelmelerine de neden olabilecektir. Ayrıca 2018 yılında güncellenen Milli Eğitim Bakanlığı (MEB), Coğrafya Öğretmenliği Özel Alan Yeterlilikleri kapsamında en fazla yer, alan bilgi ve becerilerine ayrılmıştır (MEB, 2018).

2018 Coğrafya Öğretmenliği programındaki Jeomorfoloji, Klimatoloji, Bitki Coğrafyası, Hidrografya, Toprak Coğrafyası, Nüfus Coğrafyası, Yerleşme Coğrafyası, Sanayi Coğrafyası, Tarım Coğrafyası, Ulaşım Coğrafyası ve Turizm Coğrafyası gibi Coğrafyanın bilim dalları ile ilgili konuların Fiziki Coğrafya I ve II, Beşeri Coğrafya I ve II ve Ekonomik Coğrafya I ve II dersleri içerisinde birleştirilmesi diğer önemli bir tartışma konusudur. Coğrafyanın bilim dallarına ilişkin temel bilgilerin öğretmen adaylarına kazandırılmasında yeni derslerin yetersiz olduğu iddialar arasındadır. Ayrıca bu bilim dallarının bir veya ikisi üzerinde uzmanlaşan öğretim elemanlarının yeni derslerdeki tüm konuların öğretilmesinde yetersiz kalabileceğinden endişe edilmektedir. Yine Türkiye'de öğretim elemanlarının bu tür disiplinler arası dersleri birlikte yürütmeye henüz hazır olmadıkları, öğretim programlarının bir dersin farklı öğretim elemanları tarafından birlikte yürütülebilmesine uygun olarak oluşturulmadığı ve de disiplinler arası uygulamalar için bazı prosedürel engellerin söz konusu olduğu bilinmektedir. 2018 programındaki Coğrafi Bilgi Sistemleri I ve Coğrafi Bilgi Sistemleri II dersleri Coğrafya eğitiminde Coğrafi Bilgi Sistemlerinin artan önemi de dikkate alındığında; Arazi Çalışmaları 
dersi ise coğrafya bilimine ilişkin teorik bilgilerin uygulanması ve öğretmen adaylarının bu konudaki eksikliklerinin giderilmesi açısından olumlu revizyonlar olarak değerlendirilebilir.

Bologna sürecine uyum kapsamında 2018 programındaki derslerin en az \%25'inin seçmeli olma zorunluluğu sağlanmıştır. Önceki programlarda seçmeli ders konusunda fakülteler arasında önemli farklılıklar söz konusudur. Bazı programlarda bir, hatta iki seçimlik dersin yer aldığı; kiminde ise herhangi bir seçimlik dersin olmadığı, bazı seçmeli derslerin de zorunluseçmeli derslere dönüştüğü ve seçmeli ders havuzlarında benzer içerikli, mükerrer çok sayıda dersin bulunduğu belirlenmiştir (Küçükahmet, 2007, s. 215). 2018 programında bu sorunların çözümü adına bölümlerin dersleri belirleme yetkisi büyük ölçüde kaldırılmış ve daha merkeziyetçi bir anlayışla YÖK tarafından Meslek Bilgisi, Alan Eğitimi ve Genel Kültür dersleri ile ilgili ayrı ayrı seçmeli ders havuzları oluşturulmuş ve seçmeli derslerin okutulduğu süre altı döneme çıkartılmıştır. Derslerin YÖK tarafından belirlenmesi, bu dersleri yürütebilecek öğretim elemanı sorununu da beraberinde getirmektedir. Hiçbir eğitim modelinin, o modeli işletecek insan kaynağının niteliğinin üzerinde hizmet üretemeyeceği bir gerçektir (Ataç, 2003, s. 1). Meslek Bilgisi ve Genel Kültür seçmeli derslerinin bütün fakülte öğrencilerine açılması ile sözü edilen öğretim elemanı sorunu en aza indirilerek fiziki alt yapı kaynaklarının verimli kullanılması hedeflenmiştir.

2018 programında toplam kredilerin \% 18'i Genel Kültür derslerine ayrılmıştır. Öğretmen adaylarının bir alanda uzmanlık bilgisine sahip olmasının yanı sıra; bireyi, toplumu ve dünyayı ilgilendiren konularda geniş bir dünya görüşüne ve genel kültüre sahip olmaları beklenmektedir (Çelikten ve diğerleri, 2005, s. 221). Ayrıca öğretmen adayları genel kültür bakımından yeterli bilgiye sahip olmadıklarını ifade etmektedirler (Yılmaz, 2009, s. 40). Yeni programda Genel Kültür dersleri ile ilgili en önemli değişiklikler seçmeli dersler ile ilgili olmuştur. Genel kültür seçmeli derslerini farklı programlardan öğrencilerin her dönem seçebileceği şekilde ders programlarının oluşturulması için fakülte içinde bir koordinatörlüğün oluşturulması istenmektedir. Öğretmen yetiştirme programlarında hangi tür Genel Kültür derslerinin yer alması gerektiği önemli bir tartışma konusudur. Ayrıca programda yer alan Genel Kültür seçmeli dersleri ile Öğretmen adaylarının KPSS sınavlarında karşılaştıkları Genel Kültür konuları arasında önemli farklar söz konusudur. KPSS sınavlarının Genel Kültür konuları çoğunlukla Tarih, Türkiye Coğrafyası ve Vatandaşlık Bilgileri kapsamındadır. Yeni programda Genel Kültür derslerinin oluşturulmasında KPSS Genel Kültür konuları yeterince dikkate alınmamıştır. Ayrıca yeni programda seçmeli ders havuzundaki derslerin önemli bir bölümünün yürütülmesinde Eğitim Fakültelerinin öğretim elemanı yetersizliği ortaya çıkmaktadır.

Türkiye'de ve dünyada üniversitelerdeki temel alan bilgisi ve genel kültür dersleri esasen Fen-Edebiyat ya da Temel Bilimler fakültelerinde verilmektedir. Örneğin ABD'de alan bilgisi ve genel kültür derslerini bu fakültelerden almadan öğrenciler öğretmen yetiştirme programlarına dâhil edilmemektedir (Özcan, 2011, s. 75). Öğretmen yetiştirmenin üçayağından ikisi olan temel alan bilgisi ve genel kültür derslerinin hemen hemen tamamının Eğitim Fakülteleri bünyesinde yapılmaya çalışılması sürdürülebilir bir yaklaşım değildir. Dolayısıyla başta Fen-Edebiyat fakülteleri olmak üzere diğer fakültelerle etkili bir iletişimin sağlanmas1, eğitim fakültelerinin de yapısı ve içeriğinin yeniden tartışılması ve bu konuda daha kapsamlı bir bakış açısının oluşturulması tekrar önemli hale gelmektedir. Mevcut durum eğitim fakültelerinin ikinci bir tür Fen Edebiyat Fakültesine dönüşmesi tehlikesini de beraberinde getirmektedir. Öğretmen yetiştirmenin üçayağı olan temel alan bilgisi, gelen kültür ve pedagoji bilgisinin tamamının Eğitim Fakültelerinin sorumluluğunda olması genel kültür ve alan bilgisi yetersiz öğretmenlerin yetişmesine de neden olmaktadır. Genel kültür ve alan bilgisi yetersiz bir ögretmen adayının ise çok iyi bir öğretmenlik meslek eğitimi alması söz konusu olamamaktadır (Özcan, 2011, s. 72).

2018 programlarının en dikkat çeken özelliklerinden biri de Öğretmenlik Meslek Bilgisi derslerinin sayısının ve ağırlığının artırılmasıdır. Yeni lisans programında yer alan meslek 
bilgisi derslerinin tamamına yakınının teorik derslerden oluştuğu ve bazı derslerin ise hâlihazırda yüksek lisans düzeyinde okutulan dersler olduğu dikkat çekmektedir. Özel Öğretim Yöntemleri derslerinin programdan kaldırılması ve yerine doğrudan Coğrafyanın öğretimine ilişkin derslerin programa konulması olumlu gelişmeler olarak değerlendirilebilir. Coğrafya Öğretmenliği programında alanın öğretimine ilişkin olarak zorunlu dersler kapsamında Coğrafya Öğretimi 1, Coğrafya Öğretimi 2, Coğrafya Öğrenme ve Öğretim Yaklaşımları ve Coğrafya Öğretim Programları dersleri yer almıştır. Ayrıca seçmeli ders olarak Coğrafya Ders Kitabı İncelemesi, Coğrafya Öğretiminde Materyal Tasarımı, Çevre Eğitimi, Eğitimde Harita Uygulamaları ve Sınıf İçi Öğrenmelerin Değerlendirilmesi dersleri alanın öğretimine ilişkin olarak programa yeni konulan dersler arasındadır. 2018 yılı programlarına ilişkin yönergede (YÖK, 2018, s.18) alanın öğretimi ile ilgili önceki programda sadece 3 kredilik bir ders varken (Özel Öğretim Yöntemleri 2) yeni programda ders sayısının ve kredisinin dört katına kadar artırıldığ 1 ifade edilmiştir. Ancak yine YÖK'nun güncel Pedagojik Formasyon yönergesi madde 7'de eski programdaki Özel Öğretim Yöntemleri, Öğretim Teknolojileri ve Materyal Tasarımı ve Öğretmenlik Uygulaması dersleri alan eğitimi ve öğretimine özgü dersler olarak tanımlanmaktadır. Bu çelişkili tanımlamalar ve fakültelerdeki önceki uygulamalar da dikkate alındığında 2018 Coğrafya Öğretmenliği Lisans programında alanın öğretimine ilişkin derslerin ilgili yönergede belirtildiği kadar arttırılmadığı düşünülmektedir. Ayrıca Öğretmenlik Meslek Bilgisi ve Alan Bilgisi kapsamındaki teorik bilgilerin ilgili alanda uygulanması kapsamındaki alanın öğretimine ilişkin derslerin çoğunlukla uygulama derslerinden oluşması beklenirken, bu derslerin çoğunluğunun teorik olarak yeni programda yer aldığ 1 görülmektedir. 2018 programında Alan Bilgisi kapsamındaki teorik dersler dramatik bir şekilde azaltılırken, buna karşılık Eğitim Bilimleri kapsamındaki teorik derslerin saatleri ve kredileri artırılmıştır. Dolayısıyla yeni öğretmen yetiştirme lisans programları uygulama derslerinin eksikliği ile ilgili genel eleştirilere yeterince cevap verememiştir. Ayrıca uygulama derslerine yeterince yer verilmemesi edinilen bilgiler ile gerçek dünya arasında pamuk ipinden bir bağ oluşturmaktadır (Calderhead, 1997, s. 18). Yapılan çalışmalarda öğretmen adaylarının da uygulamalı derslerin az ve yetersiz olmasından şikâyet ettiği belirlenmiştir (Akhan, 2015, s. 272; Tonga, 2012, s. 780).

2018 programının güncellenme gerekçelerinden birisi de öğretmenlik uygulamalarının daha geniş bir zamana yayılması ve öğretmen adaylarının uygulama okullarında geçirdiği sürenin artırılmasıdır (YÖK, 2018, s. 11). Öğretmen yetiştirme programlarının ilk yılından itibaren aday öğretmenlerin gözlem, okula uyum ve bir öğretmenin gün içerisinde okulda yapacağı çalışmaları öğrenme gibi deneyimler kazanması, nitelikli öğretmen yetiştirmenin önemli koşullarındandır (Maaske, 1955, s. 21). 1997 Coğrafya Öğretmenliği tezsiz yüksek lisans programında Okul Deneyimi I, Okul Deneyimi II ve Öğretmenlik Uygulaması adlı üç ders ile okul uygulamaları üç döneme yayılmış, ancak daha sonra okul-fakülte işbirliğinde yaşanan sorunlar nedeniyle okul uygulamaları iki döneme düşürülmüştür. 2018 güncellemesinde ise Okul Deneyimi dersinin kaldırılarak Öğretmenlik Uygulaması dersinin iki döneme çıkartılması ile esasen öğretmen adaylarının uygulama okullarında geçirdiği süre değişmemiştir. Öğretmen adaylarının lisans eğitimlerinin ilk üç yılında uygulama okullarından uzak kalması, Türkiye'de öğretmen yetiştirmenin önemli sorunlarından biri olmaya devam etmektedir. Oysa okul uygulamalarının sayısının arttırılması ve aday öğretmenlerin lisans öğrenimlerinin ilk yıllarından itibaren okullarda deneyim kazanabilmelerinin sağlanması gerekir (Tonga, 2012, s. 796). 2018'de Okul Deneyimi dersi, işlevsel ve etkili bir biçimde gerçekleştirilemediği gerekçesiyle kaldırılmıştır. Oysa Okul Deneyimi dersi öğretmen adaylarının okul ortamına uyum sağlaması ve öğretmenlik uygulamalarına bir basamak teşkil etmesi açısından önemlidir. Akhan (2015, s. 285) yaptığı araştırmada Okul Deneyimi dersi hakkında öğretmen adaylarının olumlu görüşe sahip olduklarını tespit etmiştir. Ayrıca Okul Deneyimi dersi kapsamında yaşanan sorunlar esasen Öğretmenlik Uygulamaları dersi için de söz konusudur. Aday öğretmen fazlalığından dolayı fakültelerin uygulama okulu bulmakta bazı sıkıntılar yaşadığ 1 da bilinen bir gerçektir. Esasen temel sorun, öğretmen yetiştirme yetki ve 
sorumluluğunun Yüksek Öğretim Kurumuna devredilmesinden bugüne Eğitim Fakülteleri ile öğretmenleri istihdam eden MEB arasında etkili bir işbirliğinin gerçekleştirilememiş olmasıdır (Özoğlu, 2010, s. 30). Bu temel sorunun çözümü ve okul uygulamalarının daha işlevsel ve etkili hale getirilmesi için 2018 yılında Öğretmenlik Uygulaması Yönergesi ve Fakülte-Okul İşbirliği Kitabı güncellenmiştir. Ayrıca ilgili sorunların çözümünde uygulama süresinin azaltılması yerine öğretmenlik programlarının kontenjanlarının düşürülmesi bir çözüm yolu olarak görülmektedir.

Günümüzde öğretmen yetiştirme programlarını en fazla etkileyen konulardan birisi de öğretim teknolojilerindeki akıl almaz gelişmelerdir. Ancak 2018 programında bu gelişmelere paralel bir şekilde öğretim teknolojilerine yeterince yer verilmediği düşünülmektedir. Önceki programdaki Öğretim Teknolojileri ve Materyal Geliştirme dersi kaldırılmış ve yerine Öğretim Teknolojileri adıyla 2 saatlik bir zorunlu ders konulmuştur. Ancak alan öğretimi kapsamındaki Materyal Tasarımı dersi seçmeli ders haline getirilmiştir. Oysa her öğretmen adayının alanına ilişskin geleneksel ya da dijital materyal geliştirme konusunda uzmanlaşması beklenmektedir. Ayrıca önceki programdaki Bilgisayar I ve Bilgisayar II dersleri 2018 programlarından kaldırılarak Bilişim Teknolojileri adlı tek bir derse düşürülmüştür.

Sonuç olarak 2018 Coğrafya Öğretmenliği Lisans Programının olumlu ve olumsuz yönlerinin tartışıldığı bu araştırmanın nihayetinde bazı öneriler ortaya konulmuştur:

- Alan Bilgisi ve Genel Kültür derslerinin etkili ve verimli bir şekilde yürütülebilmesi için Fen-Edebiyat vb. fakültelerle etkili bir koordinasyon sağlanmalıdır. $\mathrm{Bu}$ konuda sorumluluk paylaşımı adına kapsamlı düzenlemelere ihtiyaç vardır.

- Okul Deneyimi dersinin içeriği güncellenerek daha işlevsel hale getirilmeli ve öğretmen adaylarının okul uygulamalarına daha erken başlamaları sağlanmalıdır. Ayrıca öğretmen adaylarının uygulama okullarında geçirdikleri süre artırılmalıdır. $\mathrm{Bu}$ kapsamda MEB ile daha etkili bir işbirliği geliştirilmelidir.

- Öğretim teknolojilerine ilişkin derslerin programda ağırlığı artırılmalıdır.

- Fiziki Coğrafya I ve II, Beşeri Coğrafya I ve II, Ekonomik Coğrafya I ve II gibi dersler coğrafyanın çok farklı konularını içerdiğinden, farklı öğretim elemanları tarafından birlikte yürütülebilmesinin olanakları araştırılmalıdır.

- Öğretmen yetiştirme lisans programındaki ders içerikleri ile öğretmen atamaları için yapılan KPSS sınav konularının içerikleri arasındaki derin farklar giderilmelidir.

- Öğretmenlik Meslek Bilgisi kapsamında özellikle seçmeli ders havuzunda yer alan ve lisansüstü düzeyde okutulması gereken bazı teorik dersler lisans programlarından kaldırılmalı, alanın öğretimine ilişkin uygulamalı derslere daha fazla yer verilmelidir.

- Öğretmen yetiştirme lisans programları üzerindeki baskının azaltılması ve öğretmenliğin daha nitelikli hale getirilmesi için tezli yüksek lisans vb. alternatifler daha fazla tartışılmalıdır.

- Üniversite sınav yerleştirmelerinde Alan Bilgisi, Öğretmenlik Meslek Bilgisi ve Genel Kültür dersleri bağlamında özellikle öğretim elemanları açısından yetersiz olan fakülte ya da bölümlere kontenjan verilmemelidir.

Yeni öğretmen yetiştirme lisans programıyla ilgili akademik çalışmalar arttırılmalıdır. 


\section{Kaynakça}

Akhan N. E. (2015). Sosyal bilgiler öğretmen adaylarının sosyal bilgiler lisans programı üzerine düşünceleri. International Journal of Social Science, 32, 267-289.

Ataç, E. (2003). 21. Yüzyılda öğretmen eğitimi: Türkiye'de öğretmen eğitiminin değerlendirilmesi konulu panelde yaptığı açılış konuşması. Anadolu Üniversitesi Eğitim Fakültesi Dergisi, 13(2), 1-31.

Aycan, Ş. (2015). Liselere öğretmen yetiştirmede geri adım: Yüksek öğretmen okullarından pedagojik formasyon kurslarına. MSKU Eğitim Fakültesi Dergisi 2(2), 61-72.

Baltacı, C. (1999). Osmanl Devleti'nde eğitim ve öğretim, Türkler. C.XI, Ankara: Yeni Türkiye Yayınlar1.

Baskan, G. A. Aydın, A. ve Madden, T. (2006). Türkiye'deki öğretmen yetiştirme sistemine karş1laştırmalı bir bakış. Ç.Ü. Sosyal Bilimler Enstitüsü Dergisi 15(1), 35-42.

Bayram, Ö. (2003). Türkiye'de ilköğretime (6-7-8) branş öğretmeni yetiştirilmesi ve sosyal bilgiler ögretmenliği ile sosyal bilgiler dersi programlarının gelişimi (1946-1982). (Yayınlanmamış yüksek lisans tezi). Niğde Üniversitesi Sosyal Bilimler Enstitüsü, Niğde.

Çelikten, M., Şanal, M., ve Yeni, Y. (2005). Öğretmenlik mesleği ve özellikleri. Erciyes Üniversitesi Sosyal Bilimler Enstitüsü Dergisi, 19(2), 207-237.

Calderhead, J. (1997). Öğretmenlerin uzmanlı̆̆ının tanınması ve geliştirilmesi: 21. Yüzyılı bekleyen sorunlar. Uluslararası Dünya Öğretmen Eğitimi Konferansında Sunulmuş Bildiri, Ankara: Millı̂ Eğitim Basımevi.

Ercan, B. (2009). Türkiye'de ilköğretim II. kademeye sosyal bilgiler öğretmeni yetiştirme sistemleri (1923-2008). (Yayınlanmamış yüksek lisans tezi). Adnan Menderes Üniversitesi Sosyal Bilimler Enstitüsü, Aydın.

Eşme, İ. (2001). Yüksek ögretmen okulları. İstanbul: Bilgi- Başarı Yayınevi.

Forster, N. (1994). The analysis of company documentation, in C. Cassell and G. Symon, qualitative methods in organizational research: A practical guide. London: Sage Publications.

Gündüz, M. (2016). Maariften eğitime. İstanbul: Doğu-Batı Yayınları.

Karasu Avcı, E. (2017). Sosyal bilgiler öğretmen adaylarının sosyal bilgiler öğretmenliği lisans programı ile ilgili görüşleri. International Journal Of Eurasia Social Sciences, 8(27),756786.

Kaymakçı, S. (2012). Sosyal bilgiler öğretmenliği lisans programlarının içerik değerlendirmesi. Uluslararast Sosyal Bilimler Eğitimi Dergisi 2(1), 45-61.

Küçükahmet, L. (2007). 2006-2007 Öğretim yılında uygulanmaya başlanan öğretmen yetiştirme lisans programlarının değerlendirilmesi. Türk Eğitim Bilimleri Dergisi, 5(2), 203-218.

Maârif Vekâleti (1927). Maârif düsturu-I. İstanbul: Milli Matbaa.

Maarif Vekilliği (1939). Tebliğler Dergisi. Cilt 1. Ankara: Maarif Matbaası.

Maaske, R. J. (1955). Türkiye'de öğretmen yetiştirme hakkında rapor. Ankara: Maarif Basımevi.

Milli Eğitim Bakanlığı (MEB). (2015). PISA (Uluslararası öğrenci değerlendirme programı), 2015 Türkiye ulusal raporu. Ankara: MEB Ölçme Değerlendirme ve Sinav Hizmetleri Genel Müdürlüğü. 
Milli Eğitim Bakanlığ (MEB), Öğretmen Yetiştirme Genel Müdürlügüu. (2017). Sosyal bilgiler ögretmeni özel alan yeterlikleri. 173-183, Erişim adresi: http://www.oygm.meb.gov.tr.

Özcan, M. (2011). Bilgi çağında öğretmen ĕgitimi, nitelikleri ve gücü bir reform önerisi, Ankara: Türk Eğitim Derneği, Yayın No: 11687.

Özoğlu, M. (2010). Türkiye'de öğretmen yetiştirme sisteminin sorunları. Seta Analiz 17, Erişim adresi: www.setav.org.

Öztürk, C. (2006), Atatürk Devri Öğretmen Yetiştirme Politikası (2. Baskı). Ankara: Türk Tarih Kurumu Yayınları.

Özyar, A. (2001). Türkiye'de öğretmen yetiştirme politikaları. Bilim ve Aklın Aydınlı̆̆ında Eğitim Dergisi 2(21), 21-25.

Satı Bey (1918). Meşrutiyetten sonra Maârif Tarihi. Muallim, 2(19), 654-665.

Stengel, B. S. ve Tom, A. R. (1996). Changes and choices in teaching methods. Frank B. Murray (Ed), The teacher educator's handbook: Building a knowledge base for the preparation of teachers (s. 593-619) içinde. Mahwah: Lawrence Erlbaum Associates.

Tonga, D. (2012). Sosyal bilgiler öğretmenliği lisans programının değerlendirilmesi. Türk Eğitim Bilimleri Dergisi 10(4), 780-803.

Yeşiltepe, D.S. (2010). Osmanlı Döneminde coğrafyanın müfredatta yer alması ve hazırlanan ilk ders kitapları (Yayınlanmamış yüksek lisans tezi). İstanbul Üniversitesi Sosyal Bilimler Enstitüsü, İstanbul.

Yüksek Öğretim Kurumu (YÖK). (1998). Ĕgitim fakültesi öğretmen yetiştirme lisans programları. Erişim adresi: https://www.yok.gov.tr/Documents/Yayinlar.

Yüksek Öğretim Kurumu (YÖK). (2018). Öğretmen yetistirme lisans programları. Ankara: Ankara Üniversitesi Basımevi.

Yüksek Öğretim Kurumu (YÖK). (2006). Eğitim fakültelerinde uygulanacak yeni programlar hakkında açıklama. Erişim adresi: http://www.yok.gov.tr.

Yüksek Öğretim Kurumu (YÖK). (2007). Öğretmen yetiştirme ve eğitim fakülteleri 1982-2007. Erişim adresi: .

Yıldırım, A. ve Şimşek, H. (2013). Sosyal bilimlerde nitel araştırma yöntemleri. Ankara: Seçkin Yayıncilik.

Yılmaz, K. (2009). Lisans düzeyinde sosyal bilgiler eğitiminde karşılaşılan sorunlar ve çözüm önerileri: Öğretmen adaylarının görüşleri. On Dokuz Mayıs Üniversitesi Eğitim Fakültesi Dergisi, 27, 31-53.

ETİK ve BİLIMSEL İLKELER SORUMLULUK BEYANI

$\mathrm{Bu}$ çalışmanın tüm hazırlanma süreçlerinde etik kurallara ve bilimsel atıf gösterme ilkelerine riayet edildiğini yazar(lar) beyan eder. Aksi bir durumun tespiti halinde Afyon Kocatepe Üniversitesi Sosyal Bilimler Dergisi'nin hiçbir sorumluluğu olmayıp, tüm sorumluluk makale yazarlarına aittir. 